\title{
Characterization of replication and conjugation of plasmid pWTY27 from a widely distributed Streptomyces species
}

Tao Wang, Zhenhua Chen, Qiuxiang Cheng, Min Zhou, Xinli Tian, Pengfei Xie, Li Zhong, Meijuan Shen and Zhongjun Qin ${ }^{*}$

\begin{abstract}
Background: Streptomyces species are widely distributed in natural habitats, such as soils, lakes, plants and some extreme environments. Replication loci of several Streptomyces theta-type plasmids have been reported, but are not characterized in details. Conjugation loci of some Streptomyces rolling-circle-type plasmids are identified and mechanism of conjugal transferring are described.

Results: We report the detection of a widely distributed Streptomyces strain Y27 and its indigenous plasmid pWTY27 from fourteen plants and four soil samples cross China by both culturing and nonculturing methods. The complete nucleotide sequence of pWTY27 consisted of 14,288 bp. A basic locus for plasmid replication comprised repAB genes and an adjacent iteron sequence, to a long inverted-repeat (ca. $105 \mathrm{bp}$ ) of which the RepA protein bound specifically in vitro, suggesting that RepA may recognize a second structure (e.g. a long stem-loop) of the iteron DNA. A plasmid containing the locus propagated in linear mode when the telomeres of a linear plasmid were attached, indicating a bi-directional replication mode for pWTY27. As for rolling-circle plasmids, a single traA gene and a clt sequence (covering $16 \mathrm{bp}$ within traA and its adjacent $159 \mathrm{bp}$ ) on pWTY27 were required for plasmid transfer. TraA recognized and bound specifically to the two regions of the clt sequence, one containing all the four DC1 of $7 \mathrm{bp}$ (TGACACC) and one DC2 (CCCGCCC) and most of IC1, and another covering two DC2 and part of IC1, suggesting formation of a high-ordered DNA-protein complex.
\end{abstract}

Conclusions: This work (i) isolates a widespread Streptomyces strain Y27 and sequences its indigenous theta-type plasmid pWTY27; (ii) identifies the replication and conjugation loci of pWTY27 and; (iii) characterizes the binding sequences of the RepA and TraA proteins.

Keywords: Streptomyces, Plasmid, Replication, Conjugation

\section{Background}

Streptomyces species are widely distributed in natural habitats, such as soils, lakes, plants and some extreme environments [1,2]. They are Gram-positive, mycelial bacteria with high $\mathrm{G}+\mathrm{C}$ content (often $>70 \%$ ) in their DNA [3]. More than 6000 antibiotics and pharmacologically active metabolites (e.g. antiparasitic and antitumor agents, immuno-suppressants etc.) have been discovered in Streptomyces species [4]. Streptomyces species usually

\footnotetext{
* Correspondence: qin@sibs.ac.cn

Key laboratory of Synthetic Biology, Shanghai Institute of Plant Physiology and Ecology, Shanghai Institutes for Biological Sciences, the Chinese Academy of Sciences, 300 Fenglin Road, Shanghai 200032, China
}

harbor conjugative plasmids [5]. Modes of plasmid replication in Streptomyces include rolling-circle (RC) (e.g. pIJ101, pJV1, pSG5, pSN22, pSVH1, pSB24.2, pSY10 and pSNA1) [6], and uni-directional or bi-directional theta types (e.g. SCP2, pFP11 and pFP1) $[7,8]$. Some plasmids (e.g. SLP1 and pSAM2) replicate in chromosomallyintegrating/autonomous forms [9-11]. Streptomyces RC plasmids are usually small $(8-13 \mathrm{~kb})$, while theta-type plasmids are larger (31-120 kb).

Replication loci of Streptomyces RC plasmids comprise a single rep gene, a dso (double-strand origin) for initiation and termination of replication, and an sso (singlestrand origin) for conversion of the lagging strand into a

\section{Biomed Central}

(c) 2012 Wang et al.; licensee BioMed Central Ltd. This is an Open Access article distributed under the terms of the Creative Commons Attribution License (http://creativecommons.org/licenses/by/2.0), which permits unrestricted use, distribution, and reproduction in any medium, provided the original work is properly cited. 
Table 1 Strains and plasmids used in this study

\begin{tabular}{|c|c|c|}
\hline Strain and plasmid & Genotype or description & $\begin{array}{l}\text { Source or } \\
\text { reference }\end{array}$ \\
\hline \multicolumn{3}{|l|}{ Strains } \\
\hline $\begin{array}{l}\text { Streptomyces strains (Y27, Y32, Y33, Y34, Y41, Y42 } \\
\text { and G2-1) }\end{array}$ & Isolated from Gingko harboring pWTY27 & This work \\
\hline Streptomyces strains(W15, W24, W37 and W41) & Isolated from Artemisia annua $L$ harboring pWTY27 & This work \\
\hline Streptomyces strains (Z20, Z54 and Z70) & Isolated from Taxus harboring pWTY27 & This work \\
\hline S. lividans ZX7 & pro-2 str-6 rec-46 dnd SLP2- SLP3- & 34 \\
\hline S. coelicolor A3(2) & SCP1 SCP2 & 35 \\
\hline Escherichia coli DH5a & F- deoR recAl endA1 hsdR17(rk- mk+) phoA supE44 $\lambda$ - thi-1 gyrA96 relA1 & Invitrogen \\
\hline E. coli BL21 (DE3) & hsdSB(rB- mB-) $\lambda(D E 3$ [lacl lacUV5-T7 gene 1 ind1 sam7 nin5]) & Novagen \\
\hline E. coli ET12567 (pUZ8002) & dam dcm hsdM cm kan & 35 \\
\hline \multicolumn{3}{|l|}{ Plasmids } \\
\hline pSP72 & amp colEl ori & Invitrogen \\
\hline plJ702 & tsr melC plJ101 ori & 39 \\
\hline pYQ1 & A 14-kb Sacl-fragment cloned in pSP72 & This work \\
\hline pQC156 & A 2.6-kb Bcll-fragment of melC/tsr cloned in pSP72 (Bg/ll) & 26 \\
\hline pZR131 & Two 381-bp telomeres tsr melC amp colEl ori & 8 \\
\hline pWT177 & A 3.8-kb fragment (100-3941bp) cloned in pZR131 (EcoRl) & This work \\
\hline pSET152 & amp apr oriT int(phiC31) & 36 \\
\hline pWT181 & pSET152 derivative, amp tsr melC cos oriT int(phiC31) & This work \\
\hline pET28b & kan & Novagen \\
\hline pWT111 & $\begin{array}{l}\text { A 1.6-kb fragment (574-2253 bp of pWTY27) cloned in pET28b (EcoRI } \\
\text { +HindllI) }\end{array}$ & This work \\
\hline pWT371 & $\begin{array}{l}\text { A 1.7-kb fragment (8124-9836 bp of pWTY27) cloned in pET28b (Nhel } \\
\text { +HindllI) }\end{array}$ & This work \\
\hline pFX144 & $\begin{array}{l}\text { A 1.3-kb fragment (37-1328 bp of plJ773 containing oriT/apr) cloned in } \\
\text { pSP72 (Xbal) }\end{array}$ & This work \\
\hline pWT26 & $\begin{array}{l}\text { A 1.3-kb fragment (13-1369 bp of pFX144 containing oriT/apr) cloned in } \\
\text { pYQ1(EcoRV) }\end{array}$ & This work \\
\hline pWT24 & $\begin{array}{l}\text { A 5.4-kb fragment (13942-14288/1-5114 bp of pWTY27) cloned in pFX144 } \\
\text { (Sspl + Sacl) }\end{array}$ & This work \\
\hline pWT147 & A 3.8-kb fragment (100-3941 bp) cloned in pFX144 (Xbal) & This work \\
\hline pWT219 & A 3.2-kb fragment (321-3506 bp) cloned in pFX144 (Xbal) & This work \\
\hline pWT217 & A 1.9-kb fragment (321-2267 bp) cloned in pFX144 (Xbal) & This work \\
\hline pWT222 & A 2.9-kb fragment (621-3506 bp) cloned in pFX144 (Xbal) & This work \\
\hline pWT223 & $\begin{array}{l}\text { A 0.3-kb fragment (321-620 bp) containing iteron cloned in pWT222 } \\
\text { (BamHI) }\end{array}$ & This work \\
\hline pWT241 & $\begin{array}{l}\text { A 0.15-kb fragment (382-530 bp) containing iteron cloned in pWT224 } \\
\text { (BamHI) }\end{array}$ & This work \\
\hline pWT34 & A 95-bp fragment (1073-1167 bp) deleted from pWT24 & This work \\
\hline pWT33 & A 259-bp fragment (2433-2691 bp) deleted from pWT24 & This work \\
\hline pWT203 & $\begin{array}{l}\text { A 6-kb fragment containing the rep/rlrA/rorA of pSLA2 cloned in pFX144 } \\
\text { (Pvull) }\end{array}$ & This work \\
\hline pWT208 & A 3.2-kb fragment (6757-9977 bp) cloned in pWT203 (Sspl) & This work \\
\hline pWT207 & A 1.5-kb fragment (6757-8270 bp) cloned in pWT203 (Sspl) & This work \\
\hline pWT210 & A 2.2-kb fragment (7734-9977 bp) cloned in pWT203 (Sspl) & This work \\
\hline pWT225 & A 2.2-kb fragment (7734-9893 bp) cloned in & This work \\
\hline pWT224 & pWT203 (Sspl) & This work \\
\hline
\end{tabular}


Table 1 Strains and plasmids used in this study (Continued)

\begin{tabular}{lll}
\hline & A 2.1-kb fragment (7734-9818 bp) cloned in pWT203 (Sspl) & This work \\
\hline pWT242 & A 175-bp fragment (9803-9977 bp) cloned in & This work \\
\hline pWT262 & pWT224 (Sspl) & This work \\
\hline pWT231 & A 46-bp fragment (9803-9848 bp) cloned in & TWT224 (Sspl) \\
\hline pWT229 & A 87-bp fragment (9803-9889 bp) cloned in & This work \\
\hline pWT239 & pWT224 (Sspl) & This work \\
\hline pWT238 & A 100-bp fragment (9803-9902 bp) cloned in & This work \\
\hline pWT251 & pWT224 (Sspl) & This work \\
\hline pWT259 & A 128-bp fragment (9803-9930 bp) cloned in & \\
\hline pWT265 & pWT224 (Sspl) & A 150-bp fragment (9803-9952 bp) cloned in \\
\hline & pWT224 (Sspl) & This work \\
\hline & A 134-bp fragment (9844-9977 bp) cloned in & This work \\
\hline
\end{tabular}

double-stranded molecule [12]. The replication locus of the theta-type SCP2 comprises repI and repII genes and an adjacent non-coding sequence to which RepI protein binds $[7,13]$. pFP1 and pFP11 contain basic replication loci of rep and iteron types (direct repeats and/or inverted repeats), to which Rep proteins bind [8].

Conjugal transfer of Streptomyces RC plasmid (e.g. pIJ101) needs a tra gene along with a clt (cis-acting locus of transfer) site [14]. Streptomyces tra genes encode a DNA translocase resembling the chromosomal DNA translocase FtsK of E. coli or SpoIIIE of B. subtilis [3], with double-stranded DNA probably entering the recipient [15]. The TraB of pSVH1 binds to the clt sequence as multimers on the mobilized plasmid and translocates unprocessed DNA at the hyphal tip to a recipient cell [16]. Conjugal transfer of Streptomyces theta-type plasmids (e.g. SCP2 and pZL12) requires a major tra gene and two adjacent genes $[17,18]$.

In contrast to most bacteria, Streptomyces species often harbor linear plasmids $[19,20]$. Unlike the terminal protein-capped linear replicons of adenoviruses that replicate by a mechanism of strand displacement [21], Streptomyces linear plasmids start replication from a centrally located ori locus [22] and replication proceeds bi-directionally toward the telomeres [23]. At least some Streptomyces linear plasmids (e.g. pSCL1) can propagate in circular mode when the telomeres are deleted [22], while some theta-type circular plasmids (e.g. SCP2 and pFP11) can also propagate in linear mode when the telomeres from a linear plasmid are attached [8].

\section{Results}

Identification of a widely distributed Streptomyces species Y27 and its indigenous plasmid pWTY27 among endophytic Streptomyces strains

During the course of investigating naturally circular plasmids, we detected 27 plasmids among $~ 300$ newly isolated actinomycete strains from plant samples of Gingko, Taxus and Artemisia annua $L$ in China. Interestingly, 14 of them (Table 1) displayed similar sizes of ca.14-kb DNA bands on agarose gel. These plasmids were digested with $N c o$ I and all showed five bands $(\sim 8,2.2,1.7,1.3$ and $1 \mathrm{~kb})$ on gel electrophoresis (Additional file 1: Figure S1), suggesting that they were an identical plasmid (designated pWTY27).

The 16S rRNA genes of the 14 strains were PCRamplified and all showed the same sequence, resembling those of Streptomyces species (e.g. S. albidoflavus, S. globisporus and S. coelicolor, identity 99\%). The chromosomal oriC regions of these strains were also PCRamplified with primers from the conserved $d n a A$ and $d n a N$ genes and all these oriC sequences were identical. As shown in Additional file 2: Figure S2, its 1136-bp non-coding sequence was predicted to contain 25 DnaA binding-boxes (including nine forward and sixteen reverse) of $9 \mathrm{bp}([\mathrm{T} / \mathrm{C}][\mathrm{T} / \mathrm{C}][\mathrm{G} / \mathrm{A}] \mathrm{TCCAC}[\mathrm{A} / \mathrm{C}])$, resembling that of typical Streptomyces (e.g. 17 DnaA boxes of 9 bp [TTGTCCACA] for S. lividans) [24]. The genomic DNA of these strains was digested with $S s p$ I and electrophoresed in pulsed-field gel. As shown in Additional file 3: Figure S3, genomic bands of these strains were identical. 


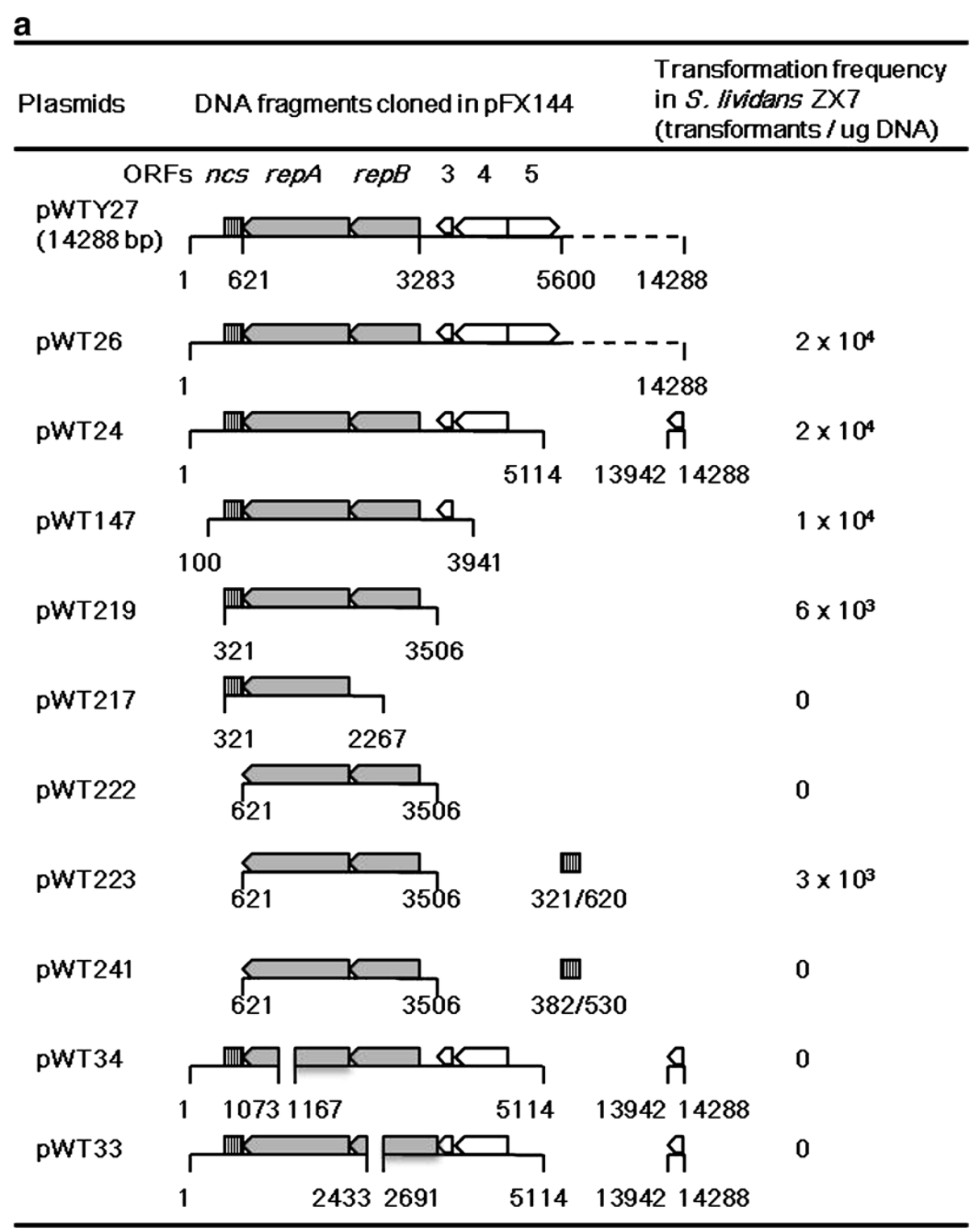

b

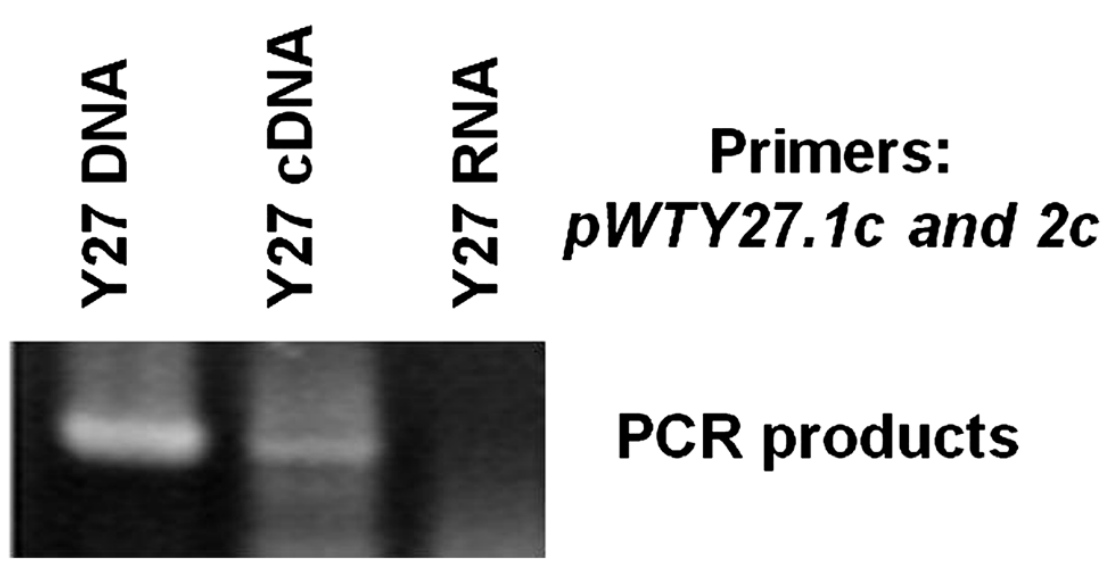

Figure 1 (See legend on next page.) 
(See figure on previous page.)

Figure 1 Identification of a pWTY27 locus required for replication in Streptomyces lividans. (a). Identification of a replication locus. Plasmids were constructed in E. coli (see Methods and Table 1), and introduced by transformation into S. lividans ZX7. Positions of these cloned fragments on pWTY27 and transformation frequencies are shown. The ncs is indicated by striped boxes, relevant genes by open arrowheads and the two replication genes by filled arrowheads. (b). RT-PCR of a transcript overlapping the consecutive replication genes. RNA of strain Y27 was isolated and reverse-transcribed into CDNA. The CDNA, RNA and Y27 genomic DNA were used as templates for PCR amplification and their products were electrophoresed in $1.5 \%$ agarose gel at $20 \mathrm{~V} / \mathrm{cm}$ for $1 \mathrm{~h}$.

These results suggested that the 14 strains were identical (designated Streptomyces sp. Y27).

\section{Sequencing and analysis of pWTY27}

The unique SacI-treated pWTY27 was cloned in an E. coli plasmid pSP72 for shotgun cloning and sequencing (see Methods). The complete nucleotide sequence of pWTY27 consisted of 14,288 bp with $71.8 \%$ GC content, resembling that of a typical Streptomyces genome (e.g. 72.1\% for S. coelicolor) [25]. Fifteen open reading frames (ORFs) were predicted by "FramePlot 4.0beta" (Additional file 4: Figure S4); seven of them resembled genes of characterized function, while eight were hypothetical or unknown genes. These ORFs were grouped into two large presumed transcriptional units ( $p$ WTY27.5-4c, $p$ WTY27.5-14; Additional file 5: Table S1). Interestingly, five ORFs of pWTY27.2c resembled these of of pSG2 of S. ghanaensis (DNA polymerase, SpdB2, TraA, TraB and resolvase). pWTY27.9 containing a domain (from 246 to 464 amino acids) for DNA segregation ATPase FtsK/SpoIIIE resembled a major conjugation Tra protein of Streptomyces plasmid pJV1 (NP_044357). Like other Streptomyces plasmids (e.g. SLP1 and SCP2), pWTY27 encodes genes showing similarity to transcriptional regulator kor (kill-override), spd

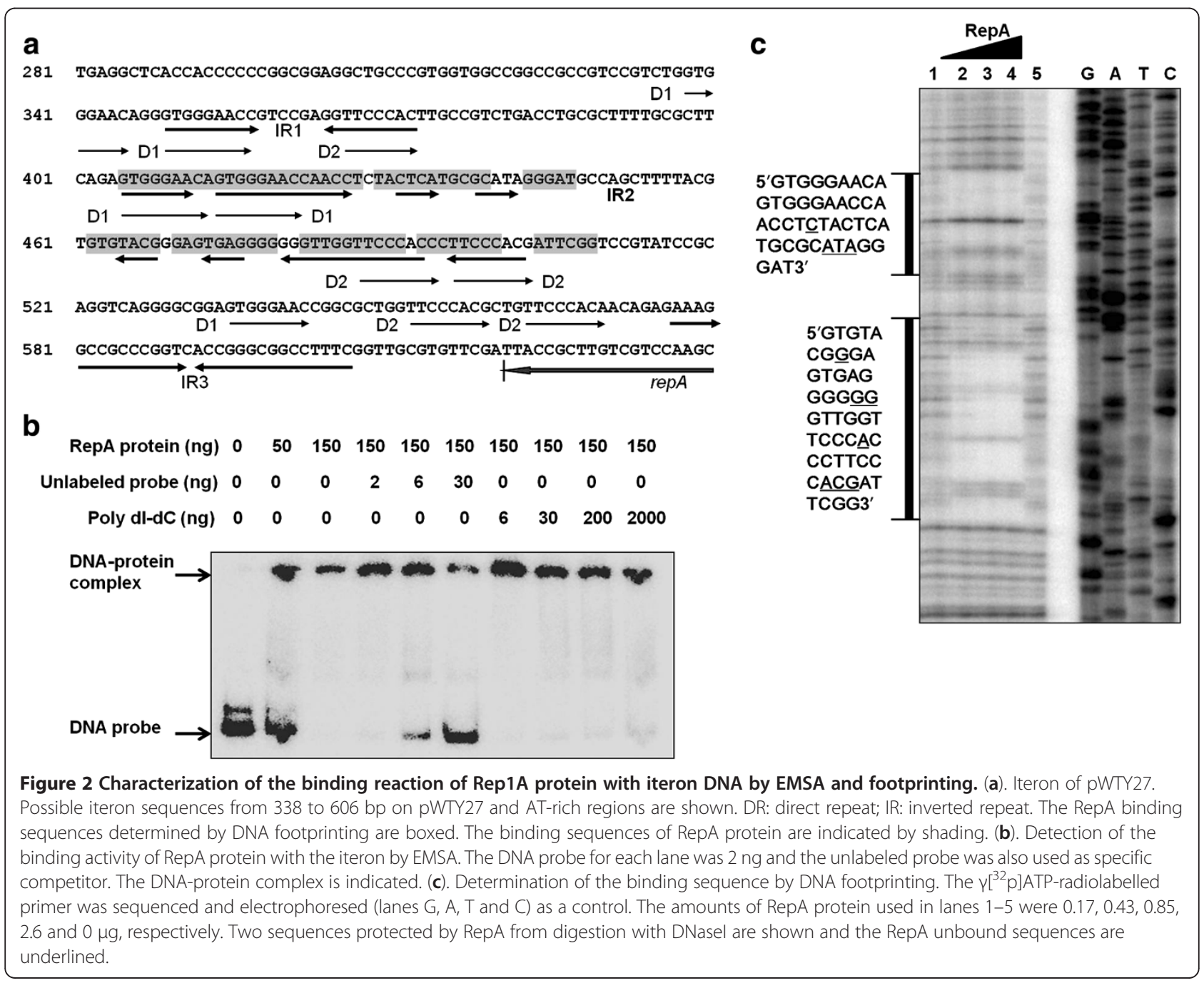


(plasmid spreading) and int (integrase) genes. Unexpectedly, pWTY27.11 resembled a chromosomally encoded phage head capsid in Nocardia farcinica IFM 10152, suggesting the occurrence of a horizontal transfer event between plasmid and phage.

\section{Characterization of replication of pWTY27}

To identify a locus for plasmid replication, various pWTY27 fragments were sub-cloned into an E. coli plasmid pFX144 containing a Streptomyces apramycin resistance marker and were introduced by transformation into S. lividans ZX7. As shown in Figure 1a, plasmids (e.g. pWT24, 26, 147 and 219) containing $p W T Y 27.1 c, 2 c$ and a 300-bp non-coding sequence (321-620 bp, ncs) could replicate in S. lividans ZX7, but deletion of $p$ WTY27.2c (i.e. pWT217 and pWT33) or pWTY27.1c (pWT34) or the ncs (pWT222) abolished propagation in S. lividans ZX7. Adding the 300-bp ncs (pWT223), but not a 149-bp ncs (382-530, pWT241), to pWT222 restored its replication activity. Co-transcription of $p W T Y 27.1 c$ and $2 c$ was confirmed by PCR amplification of their co-transcribed RNA products into cDNA (Figure 1b). These results indicated that a basic locus for pWTY27 replication was $p W T Y 27.1 c$ (designated repA), pWTY27.2c (repB) and a 300-bp (from 321 to $620 \mathrm{bp}$ ) ncs.
pWT26 was introduced by conjugation from $E$. coli ET12567 (pUZ8002) into 10 randomly-selected endophytic Streptomyces strains (different 16S rRNA sequences, e.g. Y22, Y45, Y19, Y24, Y8, Y51, Y10, Y31, Y72 and Y3), and apramycin resistant transconjugants were obtained from eight of them, indicating a wide host range for this plasmid.

\section{RepA protein binds specifically to intact IR2 of the iteron sequence in vitro}

The pWTY27 RepB was predicted to be a DNA primase/ polymerase and RepA a hypothetical protein. The 300-bp $n c s$ was predicted as an iteron containing five direct repeats of 8 bp (DR1, GTGGGAAC), five direct repeats of $7 \mathrm{bp}$ (DR2, TTCCCAC) and three pairs of inverted repeats (IR1-IR3, Figure 2a). To see if there was an interaction between the RepA protein and this iteron sequence, electrophoretic mobility shift assays for DNA-protein complex formation were employed. The 6His-tagged RepA protein was incubated with a $\left[\gamma^{-32} \mathrm{P}\right] \mathrm{ATP}$-labeled iteron DNA, and then electrophoresed and autoradiographed. As shown in Figure 2b, the "shifted" DNA bands were visualized by adding RepA protein, indicating that the RepA protein could bind to the DNA probe to form a DNA-protein complex. Formation of this complex was

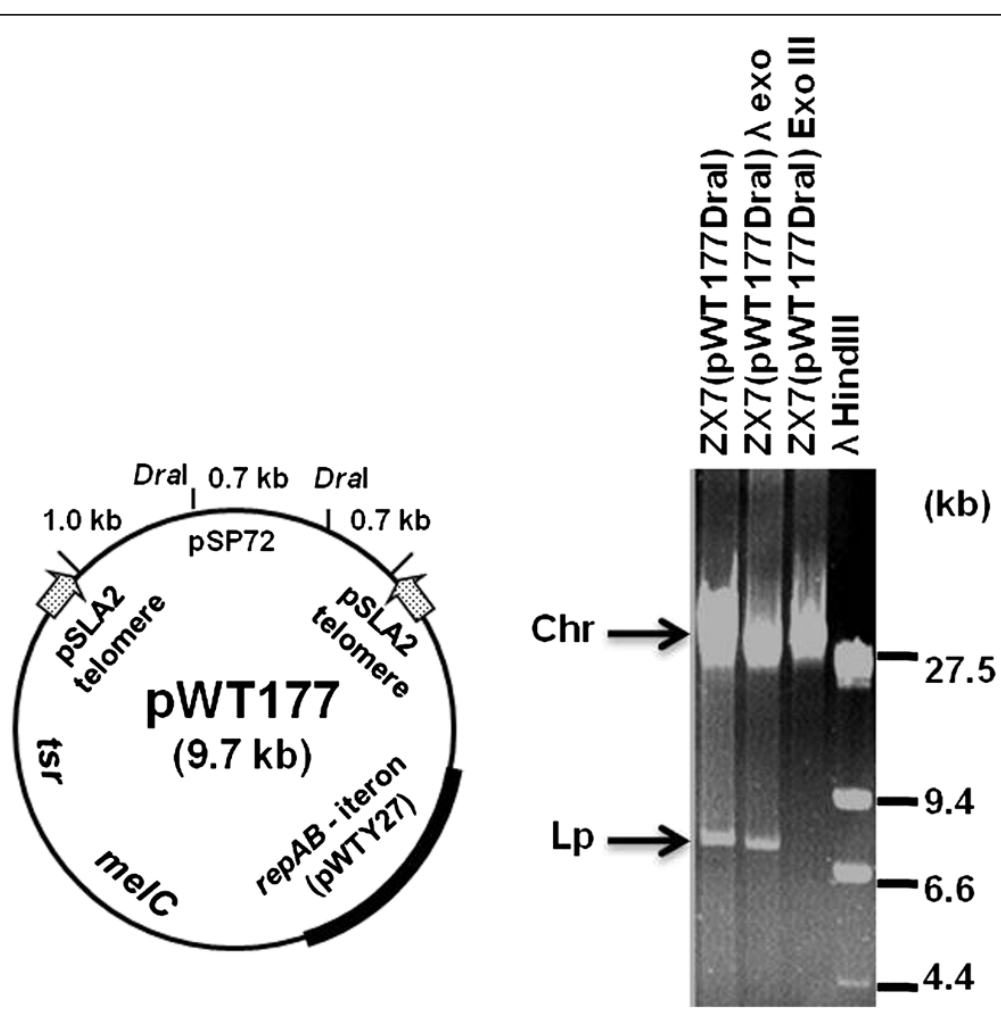

Figure 3 A plasmid containing the pWTY27 replication locus and pSLA2 telomeres propagated in linear mode in Streptomyces. Aliquots of genomic DNA were treated with $E$. coli exonuclease III and bacteriophage $\lambda$ exonuclease and electrophoresed in $0.7 \%$ agarose gel at $1.3 \mathrm{~V} / \mathrm{cm}$ for 12 h. Chromosomal (Chr) and linear plasmid (Lp) bands are indicated. 


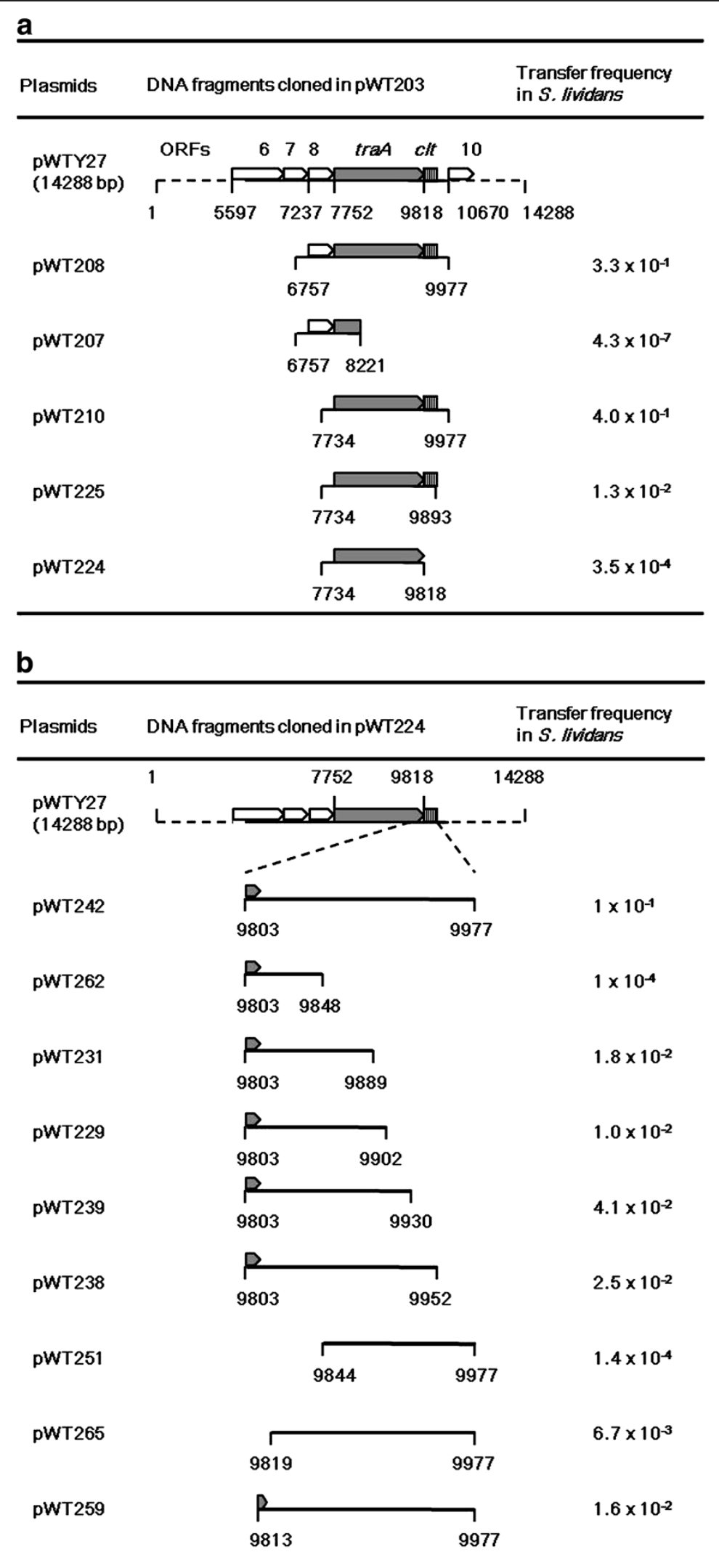

Figure 4 (See legend on next page.) 
inhibited by adding a 15-fold excess of unlabeled probe but was not affected by adding even a 1000-fold excess of polydIdC DNA as a non-specific competitor, indicating that the binding reaction of the RepA protein with iteron DNA was highly specific.

To precisely determine the binding sequence of the RepA protein and iteron DNA, a "footprinting" assay was employed. As shown in Figure 2c, two sequences (405$447 \mathrm{bp}$ and $462-509 \mathrm{bp}$ ) protected from digestion with DNaseI were visualized on adding RepA protein. These sequences (405-509 bp) covered intact IR2 (overlapping with some DR1 and DR2) of the iteron (Figure 2a).

\section{A plasmid containing the replication locus of pWTY27 propagates in linear mode when the telomeres of a linear plasmid are attached}

The replication locus of pWTY27 comprised rep and an iteron, resembling those of bi-directionally replicating Streptomyces plasmids (e.g. pFP11) [8]. To see if pWTY27 could also replicate in linear mode when the telomeres of a linear plasmid were attached, we constructed pWT177 (Figure 3), containing the replication locus of pWTY27, and two 381-bp functional telomeres of linear plasmid pSLA2 [26]. DraI-linearized pWT177 DNA from E. coli was introduced by transformation into S. lividans ZX7. Transformants were obtained at a frequency of $5 \times 10^{3} / \mu \mathrm{g}$ DNA. Genomic DNA was isolated, and a $\sim 7.3$-kb plasmid DNA band was detected on an agarose gel. As shown in Figure 3 , this band was resistant to treatment by $\lambda$ exonuclease but sensitive to $E$. coli exonuclease III, suggesting that it was a double-stranded linear DNA with free $3^{\prime}$ but blocked $5^{\prime}$ ends.

\section{Identification of a tra gene and its adjacent essential sequence for plasmid transfer}

pWTY27.9 resembled the major conjugation protein Tra of Streptomyces plasmid pJV1 [27]. As shown in Figure 4a, plasmids (e.g. pWT208 and pWT210) containing $p$ WTY27.9 and its adjacent 159-bp sequence (9819-9977) could transfer at high frequencies. Deletion of pWTY27.9 (pWT207) abolished transfer of the plasmid. Complete (pWT224) or partial deletion (pWT225) of the 159-bp sequence decreased transfer frequencies ca. 1000- and 10-fold, respectively. Thus, a basic locus for pWTY27 transfer comprised pWTY27.9 (designated traA) and its adjacent 159-bp sequence.

To precisely determine the essential segment of the short sequence for plasmid transfer, various fragments were PCR-amplified and then cloned into pWT224 containing intact $\operatorname{tra} A$ but not the 159-bp sequence. As shown in Figure 4b, a plasmid (pWT242) containing a 175-bp fragment (a 16-bp sequence within traA and the 159-bp noncoding sequence, cis-acting-locus of transfer, designated $c l t$ ) could transfer at a high frequency. Deletions of $10 \mathrm{bp}$ within traA (pWT259) decreased transfer frequency ca. 1000-fold. Deletions of 88 bp (pWT231) and 129 bp (pWT262) of the clt decreased transfer frequencies ca. 10 - and 1000-fold, respectively. These results suggested that the essential region for plasmid transfer was ca. $87 \mathrm{bp}$ covering 16 bp within traA and its adjacent 71 bp (98039889), while the 88 bp (9890-9977) next to it also played a role in plasmid transfer.

TraA protein binds specifically to the clt sequence in vitro Two trans-membrane domains (68-90 and 102-124 aa) in the 688-aa TraA protein were predicted (http://www. cbs.dtu.dk/services/TMHMM-2.0/). A truncated TraA (125-688 aa) lacking the trans-membrane domains could be expressed in E. coli as soluble protein. The 175-bp clt sequence (9803-9977) contained four direct repeats (DC1, TGACACC; DC2, CCCGCCC) and two inverted repeats (IC1 and IC2) (Figure 5a). To see if there was an interaction between TraA protein and the clt sequence, a "band-shift" assay for DNA-protein complex formation was employed. As shown in Figure 5b, TraA protein could bind to the DNA probe to form a DNA-protein complex. Formation of this complex was inhibited by adding 1-10 fold excess of unlabeled probe but was not affected by adding a 30-fold (even 1000-fold, data not shown) excess of polydIdC DNA as a non-specific competitor, indicating that the binding reaction of the TraA protein with the clt DNA was highly specific.

A "footprinting" assay was employed to precisely determine the binding sequence of TraA protein and clt DNA. As shown in Figure 5c, two sequences (9797-9849 bp and 9867-9897 bp) protected from digestion with DNase I were visualized on adding TraA protein. One sequence (9797-9849 bp) covered all the four DC1 and one DC2 and most of IC1, and another (9867-9897 bp) covered two DC2 and part of IC1 of the clt (Figure 5a). The pWTY27 sequence contained four DR1 within the clt while carrying fifteen DC2 distributing randomly in the plasmid, suggesting an essential role of the DC1 for plasmid transfer.

\section{Detection of a variety of repA of pWTY27 and oriC sequences of $\mathrm{Y} 27$ among soil samples}

By detecting the indigenous plasmid pWTY27, we have identified a widely distributed Streptomyces strain Y27 


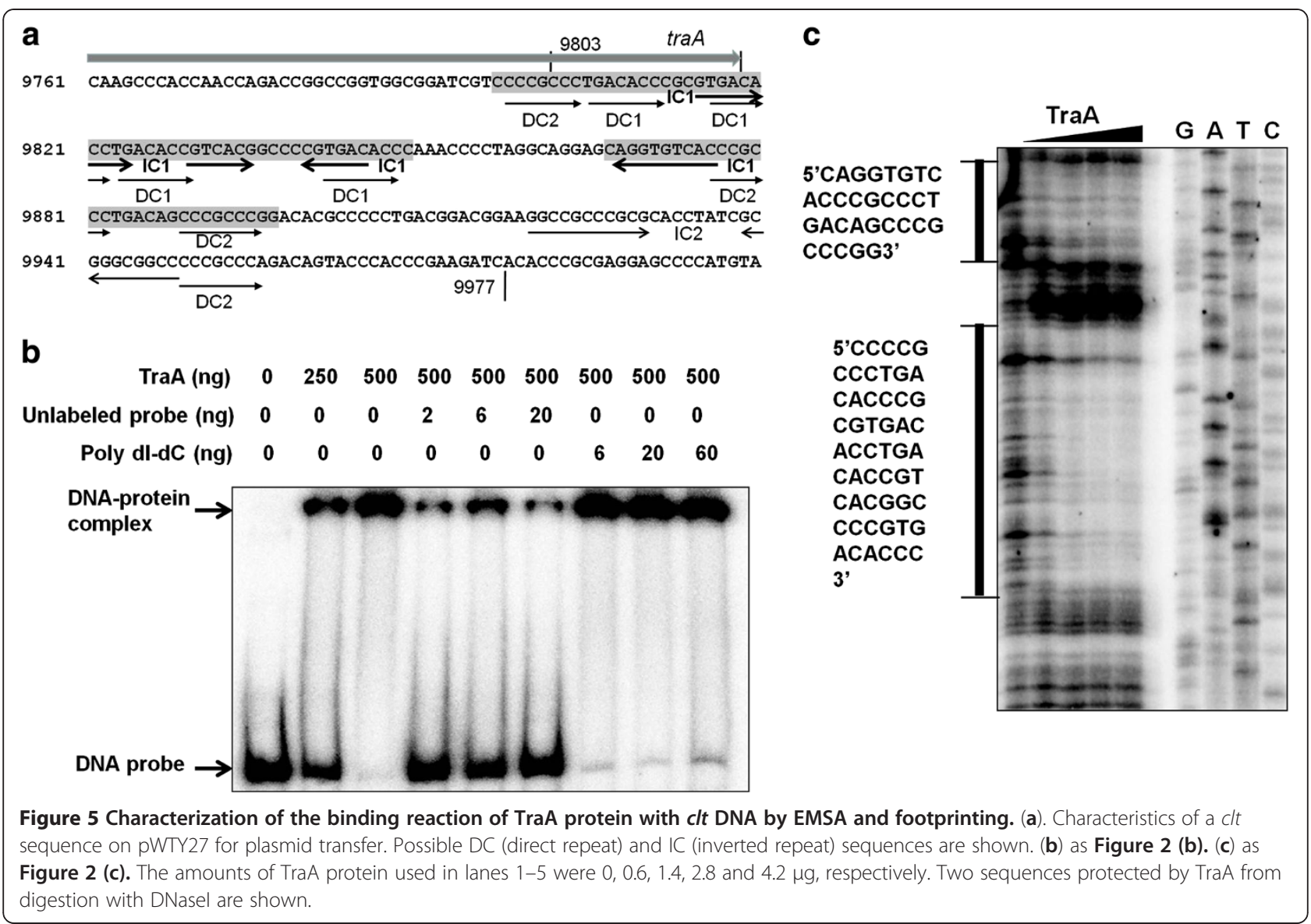

among plant samples. To see if this species along with the plasmid could also reside in soil, we collected 12 soil samples from 12 cities of nine provinces in China. Soil genomic DNA was isolated and PCR-amplified with primers from the repA of pWTY27 and the oriC of Y27. As shown in Figure 6, PCR bands were visualized from five samples (1, 2, 3, 5 and 9) for repA and also five samples $(1,3,5,8$ and 9) for oriC, while no PCR bands were obtained for the oriC of S. ceolicolor A3(2) from the twelve soil samples. There was a correlation between the rep $A$ and the oriC in four samples (1, 3, 5 and 9), while repA, but not oriC, was detected from sample 2, and oriC, but not repA, from sample 8 . These PCR bands were sequenced, showing that the repA sequences of samples 1 and 5 were identical to that of PWTY27, while one point mutation ( $\mathrm{C}$ changed to $\mathrm{A}$ at 1878-bp of pWTY27) was found in that of sample 3, one mutation ( $\mathrm{G}$ to $\mathrm{T}$ at $1895 \mathrm{bp}$ ) in sample 9, and twelve point mutations in sample 2 . The oriC sequences of samples $1,3,8$ and 9 were identical to that of $\mathrm{Y} 27$, while there was one point mutation ( $\mathrm{C}$ to $\mathrm{A}$ at 955 -bp of the 1433-bp oriC sequence) in sample 5 . These results indicated that a number of point mutations for the repA and oriC occurred from these soil samples.

\section{Discussion}

More than 500 species or sub-species in the genus Streptomyces have validly been designated and published [28]. However, whether there was some predominant Streptomces species in natural habitats was not clear. From six isolates of an endophytic (wheat plant) Streptomyces species across South Australia, a 12,855-bp plasmid pEN2701 was identified [29]. Here, we report identification of a 14,288-bp plasmid pWTY27 in an endophytic Streptomyces species Y27 from fourteen plant samples of Gingko, Taxus and Artemisia annua L across China. By integrating the egfp gene (encoding green fluorescence protein) in the Y27 chromosome and then infecting leaves of Ginkgo, however, we could not detect Y27 strains growing inside the leaves (T. Wang and Z. Qin, unpublished data). By PCR amplification of soil genomic DNA and sequencing, we found that four out of the 12 soil samples collected from 12 cities in China contained similar repA of pWTY27 and oriC of Y27. However, the absence of pWTY27-repA and YT27-oriC in certain soil samples can also be explained by the presence of a PCRinhibitor (e.g. contamination with humic acids) in the soil samples that gave negative results. The sequence of pWTY27 does not resemble that of pEN2701, and the 


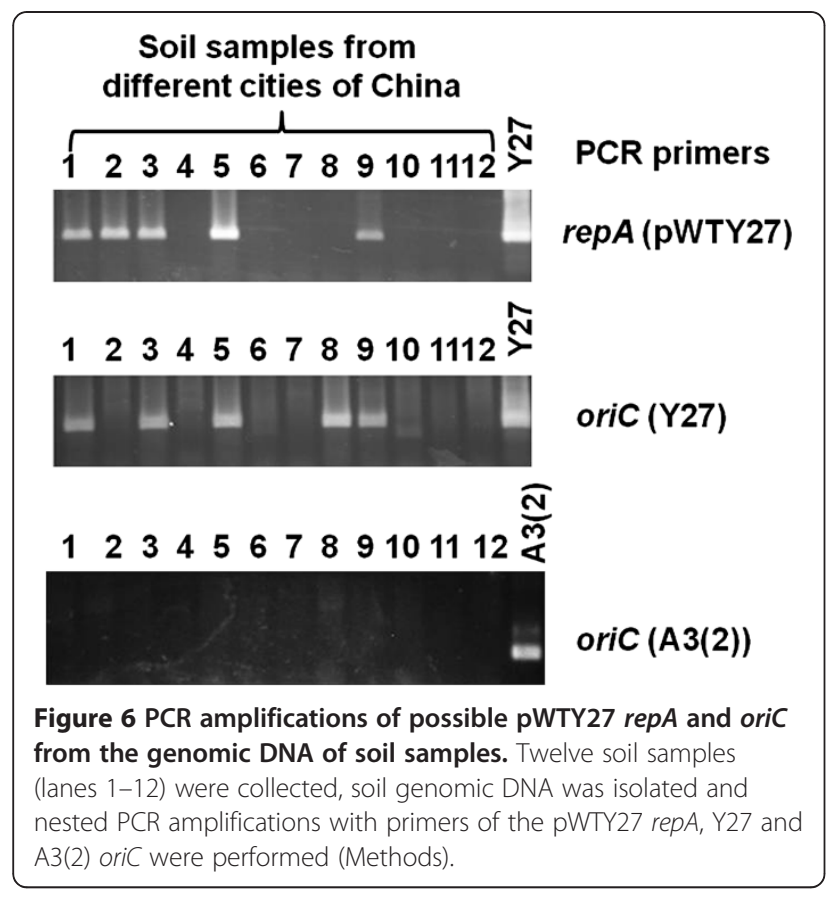

oriC sequence of $\mathrm{Y} 27$ is unique in the GenBank database. Thus, we identified a widely distributed Streptomyces species along with its indigenous plasmid from some plants and soils cross China by both culturing and nonculturing methods. Existence of a widely distributed species in natural habitats might reflect a versatile capacity to resist stresses.

The basic replication locus of pWTY27 comprises rep $A B$ genes and an iteron sequence, resembling that of Streptomyces theta-type plasmids SCP2 (repI/repII) [13], pFP11 and pFP1 (repA/iteron) [8]. Given the model of bi-directional replication of Streptomyces linear replicons [23], like SCP2 and pFP11 [8], the pWTY2-rep locus with artificially attached telomeres from a Streptomyces linear plasmid is also able to propagate in linear form, indicating that it replicates in a bi-directional mode. The RepI of SCP2 binds to an upstream sequence of the repI gene [7]. The RepA proteins of pFP1 and pFP11 bind specifically to their iterons [8]. The RepA of pWTY27 also binds highly specifically to the iteron in vitro, and further DNA "footprinting" showed that the protein binds to intact IR2, which overlaps with some DR1 and DR2, but leaving some spacers, especially the "loop" of the IR2 unprotected from digestion with DNaseI. The long IR2 sequence may fold back to form hairpin structure. In fact, DR2 (GTGGGAAC) is almost the complementary sequence of DR1 (TTCCCAC), which means it is the same repeat but on the opposite strand. These results suggest that RepA may form multimers and recongnize a second structure (e.g. long stem-loop of the IR2) of the iteron DNA (Figure 7).

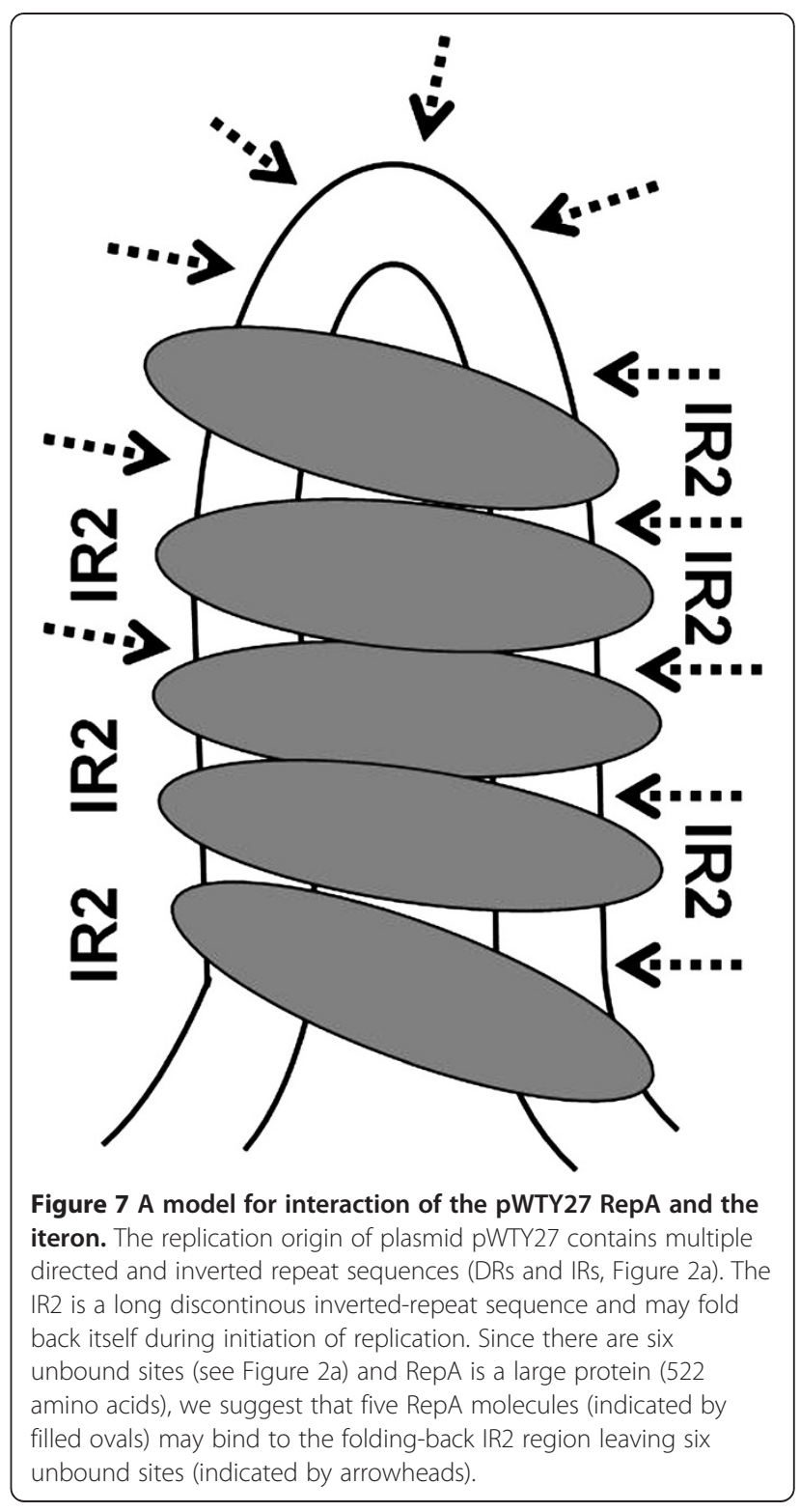

Conjugal transfer of Streptomyces theta-type plasmids (e.g. SCP2 and pZL12) requires a major tra and its adjacent genes $[17,18]$, while that of Streptomyces RC-type plasmids (e.g. pIJ101 and pJV1) needs a tra gene and a clt site $[14,30]$. The minimal pIJ101 clt-locus consists of a sequence $\sim 54 \mathrm{bp}$ in size that includes an essential imperfect inverted repeat and three direct repeats $(5 \mathrm{bp}$, GC/AAAC) sequences and is located close to the $\operatorname{kor} B$ gene [31]. The pJV1 clt region contains nine direct repeats (9 bp, CCGCACA[C/G][C/G]) and two pairs of imperfect inverted repeats [30,32]. Like these Streptomyces RC-type plasmids, conjugal transfer of the theta-type pWTY27 requires a major tra gene and its adjacent sequence. Such a clt locus in pWTY27 has a 16-bp sequence within the traA gene. The 175-bp clt sequence contains 
four direct repeats of DC1 (7 bp, TGACACC)/DC2 (7 bp, CCCGCCC) and two inverted repeats (IC1 and IC2). Thus, although the clt sequences of Streptomyces conjugative plasmids are varied, they contain multiple direct repeats and/or inverted repeats.

Reuther et al. [16] report that TraB protein of pSVH1 binds to a 50-bp clt-like sequence containing a 14-bp direct repeat, producing a protein-DNA complex too large to enter an agarose gel, indicating that multimers of TraB are bound to the DNA. Vogelmann et al. [33] show that TraB specifically recognizes repeated 8-bp motifs on pSVH1 mediated by helix $\alpha 3$ of the C-terminal winged-helix-turn-helix domain of the protein, and TraB assembles as a hexameric ring structure with a central 3.1-nm channel and forms pores in lipid bilayers. By removing the $\mathrm{N}$-terminal trans-membrane domain, TraA of pWTY27 can be expressed in E. coli as a soluble protein. TraA recognizes and binds specifically to two regions, one (9797-9849 bp) containing all the four DC1 and one DC2 and most part of IC1 and another (9867$9897 \mathrm{bp})$ covering two DC2 and part of IC1 of the clt, suggesting that formation of a high-ordered proteinDNA complex.

\section{Conclusions}

In this work, a widely distributed Streptomyces strain Y27 along with its indigenous plasmid pWTY27 from plants and soil samples cross China are identified by both culturing and nonculturing methods. The complete nucleotide sequence of pWTY27 consists of 14,288 bp. A minimal locus for plasmid replication comprises rep $A B$ genes and an adjacent iteron sequence. RepA protein binds specifically in vitro to a long inverted-repeat (i.e. IR2) of the iteron sequence. Plasmid containing the replication locus and two telomeres from Streptomyces linear plasmid can propagate in linear mode, indicating a bidirectional replication mode for pWTY27. As for rollingcircle plasmids, a single traA gene and a clt sequence on pWTY27 are required for plasmid transfer. We find that TraA binds specifically to the two regions of the clt sequence, one containing all the four DC1 of 7 bp (TGACACC) and one DC2 (CCCGCCC) and most of IC1, and another covering two DC2 and part of IC1, suggesting formation of a high-ordered DNA-protein complex.

\section{Methods}

\section{Bacterial strains, plasmids, and general methods}

Strains and plasmids used in this study are listed in Table 1. Streptomyces lividans ZX7 [34] was the host for plasmid propagation and conjugal transfer. Streptomyces culture, isolation of plasmid and genomic DNA, preparation of protoplasts and transformation, and pulsed-field gel electrophoresis followed Kieser et al. [35]. Plasmid conjugation from E. coli ET12567 (pUZ8002) into Streptomyces strains followed Bierman et al. [36]. Plasmids pSP72 and pFX144 were used as cloning vectors. E. coli strain DH5 $\alpha$ was used as cloning host. Plasmid isolation, transformation of E. coli and PCR amplification followed Sambrook et al. [37].

\section{Isolation and identification of endophytic Streptomyces}

Isolation of endophytic actinomycetes from Chinese medicinal herbs followed Cao et al. [38]. The plant samples were submerged sequentially in $75 \%$ ethanol for $5 \mathrm{~min}$, $0.9 \%$ sodium hypochlorite for $10 \mathrm{~min}, 10 \%$ sterile sodium bicarbonate for $10-20 \mathrm{~min}$ (10 min for leaf, 20 min for stem) and then washed by sterile water three times. The samples were cut into $1-\mathrm{cm}^{2}$ pieces and were inserted in different media (e.g. TSB [Tryptone Soya Broth powder $30 \mathrm{~g}$, agar $20 \mathrm{~g} / \mathrm{L}$ ] S [glucose $10 \mathrm{~g}$, tryptone $4 \mathrm{~g}, \mathrm{~K}_{2} \mathrm{HPO}_{4} \cdot 3 \mathrm{H}_{2} \mathrm{O} 0.5 \mathrm{~g}, \mathrm{MgSO}_{4} \cdot 7 \mathrm{H}_{2} \mathrm{O} 0.1 \mathrm{~g}$, $\mathrm{CaCl}_{2} \cdot 2 \mathrm{H}_{2} \mathrm{O} 0.1 \mathrm{~g}$, Ferric citrate reserving solution (1\% $(\mathrm{w} / \mathrm{v})$ citric acid, $1 \%(\mathrm{w} / \mathrm{v})$ ferric citrate) $1 \mathrm{ml}$, trace element solution $\left(\mathrm{H}_{3} \mathrm{BO}_{3} 1.5 \mathrm{~g}, \mathrm{MnSO}_{4} \cdot \mathrm{H}_{2} \mathrm{O} 0.49 \mathrm{~g}, \mathrm{ZnSO}_{4} \cdot 7 \mathrm{H}_{2} \mathrm{O}\right.$ $0.6 \mathrm{~g}, \mathrm{CuSO}_{4} \cdot 5 \mathrm{H}_{2} \mathrm{O} 0.1 \mathrm{~g},\left(\mathrm{NH}_{4}\right)_{6}\left(\mathrm{Mo}_{7} \mathrm{O}_{2}\right)_{4} \cdot 4 \mathrm{H}_{2} \mathrm{O} 0.2 \mathrm{~g}$, $\left.\mathrm{CoSO}_{4} \cdot 7 \mathrm{H}_{2} \mathrm{O} 0.01 \mathrm{~g}\right) 1 \mathrm{ml}$, agar $20 \mathrm{~g} / \mathrm{L}$ ] and Gause's synthetic agar [soluble starch $20 \mathrm{~g}, \mathrm{KNO}_{3}, 1 \mathrm{~g}, \mathrm{NaCl} 0.5 \mathrm{~g}$, $\mathrm{K}_{2} \mathrm{HPO}_{4} \cdot 3 \mathrm{H}_{2} \mathrm{O} 0.5 \mathrm{~g}, \mathrm{MgSO}_{4} \cdot 7 \mathrm{H}_{2} \mathrm{O} 0.5 \mathrm{~g}, \mathrm{FeSO}_{4} \cdot 7 \mathrm{H}_{2} \mathrm{O}$ $0.01 \mathrm{~g}$, agar $20 \mathrm{~g} / \mathrm{L}$ ]) containing $25 \mathrm{ppm} \mathrm{K}_{2} \mathrm{Cr}_{2} \mathrm{O}_{4}, 15 \mathrm{ppm}$ nalidixic acid and $25 \mathrm{ppm}$ nystatin. After incubation at $30^{\circ} \mathrm{C}$ for four weeks, actinomycete colonies were picked. Actinomycete strains were identified as Streptomyces strains by PCR amplification (primers: $5^{\prime}$-AGAGTTTGATCCT GGCTCAG- $3^{\prime}$ and $5^{\prime}$-TCAGGCTACCTTGTTACGA CTT3 $^{\prime}$ ) and sequencing of the $16 \mathrm{~S}$ rRNA genes. The sequence of the 16S rRNA gene of Y27 was deposited in the GenBank under accession number JN207128.1.

Cloning and sequencing of Streptomyces plasmid pWTY27 pWTY27 DNA was digested with restriction endonucleases ApaI, BamHI, BclI, BglII, ClaI, EcoRI, HindIII, KpnI, MluI, NcoI, NheI, PstI, SacI, XbaI and XhoI to make a restriction map, and the unique $S a c l$-digested plasmid DNA was cloned into pSP72 to obtain pYQ1. Shotgun cloning and sequencing of PYQ1 were performed on an Applied Biosystems Genetic Analyzer model 377 at the Chinese Human Genome Center in Shanghai. Analysis of Streptomyces protein coding regions was performed with "FramePlot 4.0 beta" (http://nocardia.nih.go.jp/fp4/), and ATG or GTG or TTG was used as start codons. Sequence comparisons and protein domain searching were done with software from the National Center for Biotechnology Information (http://www.ncbi.nlm.nih.gov/Blast.cgi). DNA secondary structures (e.g. direct repeats and inverted repeats) were predicted with "DNA folder" (http://mfold. rna.albany.edu/?q=mfold/DNA-Folding-Form) and "Clone manager version 9" (http://www.scied.com/pr_cmpro. 
htm). The GenBank accession number for the complete nucleotide sequence of pWTY27 is GU226194.2.

\section{Identification of a locus of pWTY27 for replication in Streptomyces lividans}

Apramycin resistant transformants in S. lividans ZX7 were obtained for plasmid pWT24 carrying a 5.4-kb fragment (13942-14288/1-5114 bp of pWTY27). Various segments of the 5.4-kb sequence were PCR amplified and cloned in pFX144 to obtain plasmids pWT147, pWT219, pWT217 and pWT222. Sequences of 95 bp (1073-1167 and 259 bp (2433-2691 of pWT24 were deleted by digesting with MluI and NotI to obtain pWT34 and pWT33, respectively. These pWTY27-derived plasmids were constructed in E. coli $\mathrm{DH} 5 \alpha$ and introduced by transformation into S. lividans ZX7. To compare transformation frequencies of plasmids in different experiments, we used $0.1 \mathrm{ng}$ DNA (diluted from a concentrated solution) of Streptomyces plasmid pIJ702 [39] each time and took $1 \times 10^{6}$ transformants per $\mu \mathrm{g}$ DNA as a control frequency.

\section{Reverse transcription PCR assay}

Strain Y27 was inoculated into tryptone soya broth (TSB, Oxoid) liquid medium, and RNA was isolated following Kieser et al. [35]. The RNA samples were treated with DNase I (RNase-free, Takara) to remove possible contaminating DNA and reverse-transcribed into cDNA by using SuperScriptTM III Reverse Transcriptase (Invitrogen). Two primers (5'-GTGAATCTTGGGCTCGC CCTTG-3' $/ 5^{\prime}$ - GCCGAGAAGTGCATCCGCAAC-3'; the expected size of the PCR product is $302 \mathrm{bp}$ ) were used to allow amplification of segments extending from each replication gene into its immediate neighbor. PCR conditions were: template DNA denatured at $95^{\circ} \mathrm{C}$ for $5 \mathrm{~min}$, then $95^{\circ} \mathrm{C} 30 \mathrm{~s}, 58^{\circ} \mathrm{C} 30 \mathrm{~s}, 72^{\circ} \mathrm{C} 30 \mathrm{~s}$, for 30 cycles.

\section{Electrophoretic mobility shift assay (EMSA)}

The repA gene (621-2198 bp) of pWTY27 was cloned into the EcoRI and HindIII sites of E. coli plasmid pET28b to obtain pWT111, which was then introduced into $E$. coli BL21 (DE3). $1 \mathrm{mM}$ IPTG (isopropyl- $\beta-\mathrm{D}$ thiogalactopyranoside) was added to a log-phase culture at $16^{\circ} \mathrm{C}$ for $12 \mathrm{~h}$ to induce over-expression of the cloned gene. The 6 His-tagged RepA protein was eluted in buffer containing imidazole and was purified to $~ 90 \%$ homogeneity by $\mathrm{Ni}^{2+}$ column chromatography following the supplier's instructions (Qiagen). The 300-bp sequence (321-620) was PCR-amplified and end-labeled with $\left[\gamma^{-}{ }^{32} \mathrm{P}\right]$ ATP using T4 polynucleotide kinase (New England BioLabs). The DNA-binding reaction was performed at room temperature for $10 \mathrm{~min}$ in buffer $(20 \mathrm{mM}$ Tris$\mathrm{HCl}$ at $\mathrm{pH} 7.5,100 \mathrm{mM} \mathrm{NaCl}, 1 \mathrm{mM}$ ATP and 10\% glycerol). PolydIdC DNA was used as non-specific competitor and unlabeled probe as specific competitor. The reaction complexes were separated on a $5 \%$ native polyacrylamide gel in $0.5 \times$ Tris-borate-EDTA buffer at $120 \mathrm{~V}$ for $1 \mathrm{~h}$. Gels were dried and analyzed using the Phosphorimager (Fuji).

Similarly, the truncated traA gene (8124-9836 bp) of pWTY27 was cloned in pET28b to yield pWT371. The 6 His-tagged TraA protein was purified by $\mathrm{Ni}^{2+}$ column chromatography and was incubated with the 175-bp (9803-9977) PCR fragment labeled with $\left[\gamma^{-}{ }^{32} \mathrm{P}\right] \mathrm{ATP}$ at room temperature for $15 \mathrm{~min}$.

\section{DNA footprinting}

The DNase I footprinting assay followed Pan et al. [40]. Primer FTr (5'-TCGAACACGCAACCGAAAGGCCG3') was end-labeled with $\left[\gamma-{ }^{32} \mathrm{P}\right] \mathrm{ATP}$ using T4 polynucleotide kinase, and then a 300-bp (321-620) DNA fragment was PCR-amplified with primers ${ }^{32} \mathrm{PFTr}$ and FTf (5'-CGGCCGCCGTCCGTCTGGTG-3'), followed by purification with the Wizard SV Gel and PCR Clean-Up System (Promega). Ca. 40-ng labeled DNA and different amounts $(0.17,0.43,0.85$ and $2.6 \mu \mathrm{g}$ ) of the purified RepA protein were incubated at room temperature for $10 \mathrm{~min}$ in a $56-\mu \mathrm{l}$ binding buffer $(20 \mathrm{mM}$ TrisHCl $\mathrm{pH}$ 7.5, $100 \mathrm{mM} \mathrm{NaCl}, 1 \mathrm{mM}$ ATP-Na, 10\% glycerol). 1 Unit DNase I (Promega) was added for $1 \mathrm{~min}$ and the reaction was stopped by adding $50 \mu \mathrm{l}$ stop solution $(20 \mathrm{mM}$ EGTA, pH 8.0). DNA was extracted with acid phenol/ chloroform solution and precipitated with isopropanol and ethanol. Sequencing ladders were prepared with FTr using the SILVER SEQUENCETM DNA Sequencing Reagents (Promega). The digestion products together with the ladders were analyzed in $6 \%$ polyacrylamide (adding $7 \mathrm{M}$ urea) gel. Gels were dried and scanned with the Phosphorimager.

Similarly, to determine the binding sequence of TraA protein and clt sequence, primer Fcltf $\left(5^{\prime}\right.$-CAAGGA CTTCATGGACTGGTGCGA-3 ${ }^{\prime}$,) was end-labeled with $\left[\gamma^{-32} \mathrm{P}\right]$ ATP, and then a 406-bp (9671-10077) DNA fragment was PCR-amplified with primers ${ }^{32} \mathrm{PF}$ cltf and Fcltr (5'-CGTGCTCGGCCTGCTCCAGGA-3'). About $40 \mathrm{ng}$ labeled DNA and different amounts $(0.6,1.4,2.8$ and $4.2 \mu \mathrm{g})$ of the purified TraA protein were incubated at room temperature for $15 \mathrm{~min}$.

\section{Identification of a locus for pWTY27 transfer in Streptomyces lividans}

To identify a locus for plasmid conjugal transfer, various pWTY27 fragments around pWTY27.9 were cloned in E. coli plasmids pWT203 which contained the rep/rlrA/ $\operatorname{ror} A$ genes required for replication and stable inheritance of the non-conjugative Streptomyces plasmid pSLA2 (31) or pWT224 (carrying intact traA). These plasmids were introduced by transformation into $S$. lividans ZX7 to produce donor strains for conjugation. The recipient 
strain was S. lividans ZX7 with a chromosomally integrating plasmid pWT181 containing the integrase gene of ФC31 [41] and selection marker tsr. About equal amount $\left(\mathrm{ca} .10^{8}\right)$ of spores of the donor and recipient strains were mixed and incubated at $30^{\circ} \mathrm{C}$ for 5 days. Spores were harvested, diluted in water and plated equally on Luria-Bertani (LB) medium (thiostrepton, $50 \mathrm{mg} / \mathrm{L}$ ), LB (apramycin, $50 \mathrm{mg} / \mathrm{L}$ ) and LB (thiostrepton + apramycin). The frequency of plasmid transfer $=100 \times$ ratio of colonies on LB (thiostrepton + apramycin) to colonies on LB (apramycin).

\section{Isolation of soil genomic DNA and PCR amplifications of the PWTY27 repA and oriC}

Twelve soil samples from 12 cities in nine provinces (Wuhan, Huanggang and Xianning cities of Hubei, Changde and Hengyang of Hunan, Nanjin of Jiangsu, Linyi of Shandong, Anyan of Henan, Xingtai of Hebei, Guiling of Guangxi, Shanghai, and HongKong) in China were collected. Ca. 0.2-g soil sample and $0.5 \mathrm{~g}$ glass beads mixed in $1 \mathrm{ml}$ buffer SLX Mlus were vibrated for $5 \mathrm{~min}$ and then were lysed in buffer DS at $90^{\circ} \mathrm{C}$ for $10 \mathrm{~min}$. Crude genomic DNA was isolated by using the E.Z.N.A ${ }^{\text {TM }}$ Soil DNA Kit (Omega). To amplify the pWTY27 repA from the soil DNA, nested PCR amplifications were employed [42]. The first round of a PCR reaction was performed using primers (5'-CAGGTCAGGGTGCC CATGCCGTAC-3', 5'-CGTACCCGCCTTGTACGTCC GCAG-3') and KOD FX enzyme (Toyoba) under conditions $\left(98^{\circ} \mathrm{C} 10 \mathrm{~s}, 60^{\circ} \mathrm{C} 30 \mathrm{~s}, 68^{\circ} \mathrm{C} 40 \mathrm{~s}\right.$ for 30 cycles), and then $1 \mu \mathrm{l}$ PCR product was added for the second round of the PCR reaction with primers (5'-CGGTCGCTCTGCT GCACCCAG-3 ${ }^{\prime}, \quad 5^{\prime}$-GCGAGCCCAAGATTCACCGTC TG-3') under conditions $\left(98^{\circ} \mathrm{C} 10 \mathrm{~s}, 58^{\circ} \mathrm{C} 30 \mathrm{~s}, 68^{\circ} \mathrm{C} 30 \mathrm{~s}\right.$ for 20 cycles). Similarly, to amplify the Y27 oriC, two primers (5'-ATGCACGCCGACCGCAAGATC-3', 5'-AY RSGTTGCCGAACAGTGGACA-3') were used for the first round, and nested primers (5'-CCACGGCCCC GAATCCGCCTC-3', 5'- GCACAACACCGGCCTGC CTGTG-3') for the second round of the PCR reactions. To amplify the $\mathrm{A} 3(2)$ oriC, primers used in the first round reaction were the same as in the $\mathrm{Y} 27$ oriC, and new nested primers (5'-GCCTTTCCCATGCCCCT.GG GT-3' ${ }^{\prime} 5^{\prime}$-CCTGCCCTGATGATCCCTCACCAG $-3^{\prime}$ ) for the second round of the PCR reactions.

\section{Additional files}

Additional file 1: Figure S1. Identification of fourteen indigenous plasmids. Fourteen plasmids from endophytic Streptomyces strains were digested with $\mathrm{Ncol}$ and electrophoresed in $1 \%$ agarose gel at $6.7 \mathrm{~V} / \mathrm{cm}$ for $4 \mathrm{~h}$. Sizes of five bands are indicated.

Additional file 2: Figure S2. Features of the 1136-bp sequence of the Y27 chromosomal oriC between the dnaA and dnaN genes. Taking the conserved DnaA binding-boxes of $9 \mathrm{bp}$ (TTGTCCACA) in the $\mathrm{S}$. lividans oriC as a reference [24], 25 DnaA binding-boxes of 9 bp (forward indicated by arrowheads and reverse by dashed arrowheads) for the Y27 oriC are predicted by the Vector NTI ${ }^{\circledR} 9.0$ software (Invitrogen). Two ATrich sequences are boxed.

Additional file 3: Figure S3. Identification of fourteen endophytic Streptomyces strains. The plug-embedded mycelium of fourteen endophytic Streptomyces strains was digested with Sspl and electrophoresed in a $1.0 \%$ pulsed-field gel at $8.6 \mathrm{~V} / \mathrm{cm}, 10 \mathrm{~s}$ to $60 \mathrm{~s}$ switch time and $140 \mathrm{C}$ for $22 \mathrm{~h}$

Additional file 4: Figure S4. Schematic map of pWTY27. Predicted ORFs and their transcription directions are indicated by arrowheads. The replication (repA and repB), transfer (traA) and other genes (int: integrase; phc: phage capsid; kor: kill-override; spd: spread) and site (iteron) are shown

Additional file 5: Table S1. Predicted ORFs of plasmid pWTY27. Detailed information and possible functions of the fifteen ORFs of pWTY27.

\section{Competing interest}

The authors declare no conflict of interest.

\section{Authors' contributions}

TW designed and performed all the experiments. ZC, QC, MZ, XT and LZ isolated endophytic Streptomyces strains and identified plasmids. PX and MS constructed plasmids. ZJQ was involved in project design, and prepared the manuscript. All authors read and approved the final manuscript.

\section{Acknowledgements}

We are very grateful to Sir David Hopwood for critical reading of and useful suggestions on the manuscript. This work was supported by grants from National "973" project (2011CBA00801), National Nature Science Foundation of China (31121001) and the Chinese Academy of Sciences project (KSCX2EW-G-13).

Received: 5 August 2012 Accepted: 26 October 2012

Published: 7 November 2012

\section{References}

1. Goodfellow M, Williams ST: Ecology of actinomycetes. Ann Rev Microbiol 1983, 37:189-216.

2. $X u L H$, Tian $Y Q$, Zhang YF, Zhao LX, Jiang CL: Streptomyces thermogriseus, a new species of the genus Streptomyces from soil, lake and hot-spring. Int I Syst Bacteriol 1998, 48:1089-1093.

3. Hopwood DA: Soil to genomics: the Streptomyces chromosome. Annu Rev Genet 2006, 40:1-23.

4. Bérdy J: Bioactive microbial metabolites. J Antibiot (Tokyo) 2005, 58:1-26.

5. Hopwood DA, Kieser T: Conjugative plasmids of Streptomyces. In Bacteria Conjugation. Edited by Clewell DB. New York: Plenum Press; 1993:293-311.

6. Grohmann E, Muth G, Espinosa M: Conjugative plasmid transfer in grampositive bacteria. Microbiol Mol Biol Rev 2003, 67:277-301.

7. Fong R, Vroom JA, Hu Z, Hutchinson CR, Huang J, Cohen SN, Kao CM: Characterization of a large, stable, high-copy-number Streptomyces plasmid that requires stability and transfer functions for heterologous polyketide overproduction. Appl Environ Microbiol 2007, 73:1296-1307.

8. Zhang R, Zeng A, Fang P, Qin Z: Characterization of the replication and conjugation loci of Streptomyces circular plasmids pFP11 and pFP1 and their ability to propagate in linear mode with artificially attached telomeres. Appl Environ Microbiol 2008, 74:3368-3376.

9. Bibb MJ, Ward JM, Kieser T, Cohen SN, Hopwood DA: Excision of chromosomal DNA sequences from Streptomyces coelicolor forms a novel family of plasmids detectable in Streptomyces lividans. Mol Gen Genet 1981, 184:230-240

10. Omer CA, Cohen SN: Plasmid formation in Streptomyces: excision and integration of the SLP1 replicon at a specific chromosomal site. Mol Gen Genet 1984, 196:429-438.

11. Pernodet JL, Simonet JM, Guerineau M: Plasmids in different strains of Streptomyces ambofaciens: free and integrated form of plasmid pSAM2. Mol Gen Genet 1984, 198:35-41. 
12. Khan SA: Plasmid rolling-circle replication: highlights of two decades of research. Plasmid 2005, 53:126-136.

13. Haug I, Weissenborn A, Brolle D, Bentley S, Kieser T, Altenbuchner J: Streptomyces coelicolor A3(2) plasmid SCP2*: deductions from the complete sequence. Microbiology 2003, 149(Pt 2):505-513.

14. Pettis GS, Cohen SN: Transfer of the plJ101 plasmid in Streptomyces lividans requires a cis-acting function dispensable for chromosomal gene transfer. Mol Microbiol 1994, 13:955-964.

15. Possoz C, Ribard C, Gagnat J, Pernodet JL, Guerineau M: The integrative element pSAM2 from Streptomyces: kinetics and mode of conjugal transfer. Mol Microbiol 2001, 42:159-166.

16. Reuther J, Gekeler C, Tiffert Y, Wohlleben W, Muth G: Unique conjugation mechanism in mycelial streptomycetes: a DNA-binding ATPase translocates unprocessed plasmid DNA at the hyphal tip. Mol Microbiol 2006, 61:436-446.

17. Brolle DF, Pape $H$, Hopwood DA, Kieser T: Analysis of the transfer region of the Streptomyces plasmid SCP2. Mol Microbiol 1993, 10:157-170.

18. Zhong L, Cheng Q, Tian X, Zhao L, Qin Z: Characterization of the replication, transfer and plasmid/lytic phage cycle of the Streptomyces plasmid-phage pZL12. J Bacteriol 2010, 192:3747-3754

19. Hayakawa T, Yanaka T, Sakaguchi K, Otake N, Yonehara H: A linear plasmid-like DNA in Streptomyces sp. producing lankacidin group antibiotics. J Gen Appl Microbiol 1979, 25:255-260.

20. Kinashi H, Shimaji M, Sakai A: Giant linear plasmids in Streptomyces which code for antibiotic biosynthesis genes. Nature 1987, 328:454-456.

21. Salas M: Protein-priming of DNA replication. Annu Rev Biochem 1991, 60:39-71.

22. Shiffman D, Cohen SN: Reconstruction of a Streptomyces linear replicon from separately cloned DNA fragments: existence of a cryptic origin of circular replication within the linear plasmid. Proc Nat Acad Sci USA 1992, 89:6129-6133.

23. Chang PC, Cohen SN: Bidirectional replication from an internal origin in a linear Streptomyces plasmid. Science 1994, 265:952-954.

24. Zakrzewska-Czerwinska J, Schrempf H: Characterization of an autonomously replicating region from the Streptomyces lividans chromosome. J Bacteriol 1992, 174:2688-2693.

25. Bentley SD, Chater KF, Cerdeno-Tarraga AM, Challis GL, Thomson NR, James KD, Harris DE, Quail MA, Kieser H, Harper D, Bateman A, Brown S, Chandra G, Chen CW, Collins M, Cronin A, Fraser A, Goble A, Hidalgo J, Hornsby T, Howarth S, Huang CH, Kieser T, Larke L, Murphy L, Oliver K, O'Neil S, Rabbinowitsch E, Rajandream MA, Rutherford K, Rutter S, Seeger K, Saunders D, Sharp S, Squares R, Squares S, Taylor K, Warren T, Wietzorrek A, Woodward J, Barrell BG, Parkhill J, Hopwood DA: Complete genome sequence of the model actinomycete Streptomyces coelicolor A3(2). Nature 2002, 417:141-147.

26. Qin Z, Shen M, Cohen SN: Identification and characterization of a PSLA2 plasmid locus required for linear DNA replication and circular plasmid stable inheritance in Streptomyces lividans. J Bacteriol 2003, 185:65756582.

27. Servín-González L, Sampieri Al, Cabello J, Galván L, Juárez V, Castro C: Sequence and functional analysis of the Streptomyces phaeochromogenes plasmid pJV1 reveals a modular organization of Streptomyces plasmids that replicate by rolling circle. Microbiology 1995, 141(Pt 10):2499-2510.

28. Goodfellow M, Kämpfer P, Hans-Jürgen B, Trujillo ME, Suzuki K, Ludwig W, Whitman WB: Bergey's manual of systematic bacteriology, Vol ume 5. 2nd edition. New York: Springer; 2011.

29. Coombs JT, Franco CM, Loria R: Complete sequencing and analysis of pEN2701, a novel 13-kb plasmid from an endophytic Streptomyces sp. Plasmid 2003, 49:86-92.

30. Servín-González L: Identification and properties of a novel clt locus in the Streptomyces phaeochromogenes plasmid pJV1. J Bacterio/ 1996, 178:4323-4326.

31. Ducote MJ, Prakash S, Pettis GS: Minimal and contributing sequence determinants of the cis-acting locus of transfer $(c / t)$ of streptomycete plasmid pIJ101 occur within an intrinsically curved plasmid region. J Bacteriol 2000, 182:6834-6841.

32. Franco B, González-Cerón G, Servín-González L: Direct repeat sequences are essential for function of the cis-acting locus of transfer $(c / t)$ of Streptomyces phaeochromogenes plasmid pJV1. Plasmid 2003, 50:242-247.
33. Vogelmann J, Ammelburg M, Finger C, Guezguez J, Linke D, Flötenmeyer M, Stierhof YD, Wohlleben W, Muth G: Conjugal plasmid transfer in Streptomyces resembles bacterial chromosome segregation by FtsK/SpollIE. EMBO J 2011, 30:2246-2254.

34. Zhou X, Deng Z, Firmin JL, Hopwood DA, Kieser T: Site-specific degradation of Streptomyces lividans DNA during electrophoresis in buffers contaminated with ferrous iron. Nucleic Acids Res 1988, 16:4341-4352

35. Kieser T, Bibb MJ, Buttner MJ, Chater KF, Hopwood DA: Practical Streptomyces Genetics. Norwich: The John Innes Foundation; 2000

36. Bierman M, Logan R, O'Brien K, Seno ET, Rao RN, Schoner BE: Plasmid cloning vectors for the conjugal transfer of DNA from Escherichia coli to Streptomyces spp. Gene 1992, 116:43-49.

37. Sambrook J, Fritsch EF, Maniatis T: Molecular Cloning: A Laboratory Manual. New York: Cold Spring Harbor Laboratory Press; 1989.

38. Cao L, Qiu Z, Dai X, Tan H, Lin Y, Zhou S: Isolation of endophytic actinomycetes from roots and leaves of banana (Musa acuminata) plants and their activities against Fusarium oxysporum f. sp. cubense. World J Microbiol Biotech 2004, 20:501-504.

39. Katz E, Thompson CJ, Hopwood DA: Cloning and expression of the tyrosinase gene from Streptomyces antibioticus in Streptomyces lividans. J Gen Microbiol 1983, 129:2703-2714.

40. Pan Y, Liu G, Yang H, Tian Y, Tan H: The pleiotropic regulator AdpA-L directly controls the pathway-specific activator of nikkomycin biosynthesis in Streptomyces ansochromogenes. Mol Microbiol 2009, 72:710-723.

41. Thorpe HM, Smith MC: In vitro site-specific integration of bacteriophage DNA catalyzed by a recombinase of the resolvase/invertase family. Proc Natl Acad Sci USA 1998, 95:5505-5510.

42. Banik JJ, Brady SF: Cloning and characterization of new glycopeptide gene clusters found in an environmental DNA megalibrary. Proc Natl Acad Sci USA 2008, 105:17273-17277.

\section{doi:10.1186/1471-2180-12-253}

Cite this article as: Wang et al:: Characterization of replication and conjugation of plasmid pWTY27 from a widely distributed Streptomyces species. BMC Microbiology 2012 12:253.

\section{Submit your next manuscript to BioMed Central and take full advantage of:}

- Convenient online submission

- Thorough peer review

- No space constraints or color figure charges

- Immediate publication on acceptance

- Inclusion in PubMed, CAS, Scopus and Google Scholar

- Research which is freely available for redistribution 